FACTA UNIVERSITATIS

Series: Philosophy, Sociology, Psychology and History Vol. 15, No 3, 2016, pp. 127 - 134

DOI: 10.22190/FUPSPH1603127T

\title{
TEKIJA AND SURROUNDING AREAS: LOVE IN RED AND BLUE
}

UDC 271.2:305-055.3(497.11)

\author{
Vesna Trifunović \\ University of Kragujevac, Faculty of Education, Jagodina, Serbia
}

\begin{abstract}
In the Djerdap gorge, squeezed between the rocky mountains and the Danube, powerful and mysterious, life takes place in small villages where everyone knows everyone, and when boys and girls come of age and become men and women they follow the customs of their ancestors. They look up to the elderly, listen to their recommendations if they did not escape the fate of patriarchal social integration; or they feel free to act in a manner which they themselves choose, if the urge to fight for freedom of choice, when it comes to "matters of the heart", is strong enough to outgrow the fear of reproach and punishment of the elderly.

Here, at the crossroads of worlds which are divided by a large river, Serbian, Romanian, and Vlach traditions meet, which are sufficiently similar so that many of their elements, especially when it comes to customs, intertwine and are reshaped a little and accepted unchanged as their own, making life on different banks similar. It is especially the case with the so-called male-female relationships and the expression of sexuality.

Findings about, for an individual and the community to which he or she belongs to, important issues of expressing affection between girls and boys in and around Tekija and manifestation of sexuality will presented in this thesis. A conversation with DjordjeTasic from Tekija shed light on some characteristics of male-female relationships typical of the Kladovo region and east borderlands of Serbia.
\end{abstract}

Key words: the young, customs, courtship, sexuality, east borderlands.

\section{INTRODUCTION}

People have been trying to arrange their relations within a society and between societies since the creation of society: a number of so-called big issues were discussed (types of society, government, power, political structure, etc.), and only after that the question of the relationship between men and women came to order, as well as the question of forming and expressing their sexuality. Issues such as relationship among the sexes and genders, the manifestation of sexuality, the attitude of the religion towards

Received July 15, 2016 / Accepted July 23, 2016

Corresponding author: Vesna Trifunović

University of Kragujevac, Faculty of Education, Milana Mijalkovica 14, 35000 Jagodina, Serbia

E-mail: dimitrije95@ptt.rs 
sexuality and sexual orientations belong to that group of issues relating to human rights and discourse of gender equality.

In particular, understanding of the place and role of women in different social teachings has passed through various stages: (a) from a rigid social attitude towards the so-called justification i.e. subordination of women and male dominance, which was often corroborated by teachings which came from different religious traditions, including Judeo-Christian (today this attitude is "spread" by the neo-fundamentalist religious movements such as radical Islam); (b) through social teachings that tried to promote the idea of the importance of women's emancipation and the idea of equality between the sexes, which influenced the construction of institutional infrastructure, in individual societies and at the international level, for their promotion and establishment of a better position of women in society (e.g. Marxism as a theoretical orientation); (c) to feminist ideas in modern times that revitalize the place and role of men in society, while in radical feminism, not only the idea of the supremacy of women, but also of a society without menis developed.

Maybe this is a good time to mention J. S. Mill's opinion about the principle that governs relationships between the sexes, and which is topical nowadays, "That the principle which regulates the existing social relations between the two sexes - the legal subordination of one sex to the other - is wrong itself, and now one of the chief hindrances to human improvement; and that it ought to be replaced by a principle of perfect equality, admitting no power or privilege on the one side, nor disability on the other" (Mill 1871). In modern times, however, the subordination is a principle that shapes life in society, including relations between the sexes, despite the omnipresent rhetoric on human rights.

The authors' intention, however, is not to engage in the deliberation on transformations of the ideas of regulation of relations between men and women, and especially not in the theme of the place and role of women in society in religious discourse, but simply in presenting the image of the relations between young men and women in the Kladovo region, more precisely in Tekija and area surrounding it, and the pattern of accepting their sexuality in the communities they belong to, before the rapid industrialization of the eastern borderlands in the seventies of the twentieth century. Our interlocutor is uncle Djordje from Tekija (DjordjeTašic), a hearty octogenarian who fondly remembers past times when young men and women courted, met and loved in a different way; and all this before the eyes of their parents. But it happened in that old Tekija, flooded due to the construction of the hydroelectric power plant. In this newly built Tekija, life has been transformed, modernized and homogenized: young people are growing up, and forming their own sexuality under the influence of the media and they are not different in any way from their peers at home and abroad. And about that, Uncle Djordje believes, he has nothing to say that others do not already know.

\section{THE BASIC SOCIO-DEMOGRAPHIC CHARACTERISTICS OF THE MUNICIPALITY OF KLADOVO}

The municipality of Kladovo represents the "final point" in the east towards Romania and it is located in the Bor region, consisting of 23 villages and 6 hamlets, of which 18 villages are located along the coast of the Danube, Tekija is one of them and it has the characteristics of a rural settlement.

Although it seems that they are at the end of a "vilayet", Kladovo and the surrounding villages have always been a meeting place of different worlds: the Danube coast was the 
place of origin of Lepenski Vir civilization, a challenge for Roman conquerors and builders, target of the Celts and Turks - to this day only Serbs have remained by a watery Danube border, staying on its left coast.

The border region of Kladovo is a special geographic unit, which has a specific economic, political and cultural significance for Serbia. Although it is a border region, it is characterized by a high degree of ethnic homogeneity (the total population consists of $92 \%$ Serbs), but it is also characterized by multi-ethnicity, primarily due to the presence of Vlachs in the total population, as well as other ethnicities (Romanians, Gypsies), although in a much smaller number. Ordinary people in Kladovolive in the same way regardless of ethnicity: the lifestyle that is imposed by the economically deprived area and area which fights against disastrous consequences of aging and depopulation.

According to the population census in the Republic of Serbia from 2011 and first preliminary results, in Bor district,where the municipality of Kladovo is situated, a constantly present decline in the total number of the population is noticeable. In the period between the two censuses (2002-2011), there was an absolute decline in the population by 22.703 inhabitants. In the municipality of Kladovo,a decline in the population by 2.978 inhabitants was also recorded.

Hydroelectric power plant "Djerdap" sank old habits and customs while economic trends in the Serbian society in recent decades caused the young and economically active population to spill across the borders of the municipality of Kladovoand into the "big wide world" - the highly developed western European societies. Data obtained from the 2011 census show that the total number of listed persons within the territory of the border municipality of Kladovo was 27227 , and the total number of inhabitants $20.635-6.534$ persons changed the place of residence by migration (the vast majority is living and working abroad).

Over 800 residents now live in Tekija and they are "struggling" with all the hardships that accompany the transitional Serbian society, not enough money, not enough good changes, not enough people and not enough young people - deficits wherever you look. The only surplus- memories, they last but they are of no use; but, maybe they could be useful, if they are only given adequate attention.

\section{FEASTS WITH GENDER (SEXUAL) DIMENSION IN THE EASTERN BORDERLANDS}

The life in Djerdapvillages, as well as in other Serbian Orthodox homogeneous areas, was spent strongly associated with the feast days and big church holidays which are in Serbia often the same as public holidays from the pre-Christian period, in regard to their way of celebration and ritual knowledge. Djurdjevdan (St. George's day) (May 6) was one of the major holidays of the year in Djerdapvillages and generally in eastern Serbia,while livestock was the important sector of industry in these areas: the rituals that are performed just before and on Djurdjevdan are primarily associated with livestock (Stanojevic 1930), but there are also elements of the rituals associated with the cult of fertility, witchcraft-love elements (Prvulović 1996), and elements whose basic purpose is protective power (Vlahović 1996) and elements which contain in themselves greenery that represents life and fertility. 


\title{
3.1. Young people and traditional customs on Djurdjevdan
}

Djurdjevdan is a holiday which is accompanied by a multitude of so-called Djurdjevdan actions focused primarily on life awakening, and associated with greenery and water. There existed a custom in Tekija and surrounding areas - on the eve of Djurdjevdan, girls and boys went into the forest to pick specific plants (geranium, poinsettia, lily, etc.) and green branches while singing special songs; they would return in the morning, young men would then, adorned, play kolo (Serbian traditional dance) by the water, and girls would decorate their houses and cattle with greenery and garlands of flowers and they would also put flowers in their hair and around their necks, while women threw green branches into thewater. This custom certainly gave the opportunity to young people to interact, to better know each other while performing ritual actions, to share happiness because of the arrival of spring - the awakening of life in nature, which certainly had an indirect impact on the awakening of their sexuality and desire for entering a new phase in the life cycle: marriage and childbearing. The old belief, that Đurđevdan's dew possesses healing powers and that it should be specifically used by girls for washing their faces, is probably associated with the cult of fertility, because dew keeps plants alive during droughts and helps them keep their fruits.

\begin{abstract}
„How it used to be on Djurdjevdan...", uncle Djordje says, "it cannot be retold... In the past that holiday had a special meaning, everything that was done on the eve or on the day of the holiday had a particular reason, nowadays people cannot understand that, everything has changed. The world has changed and rules have changed, you see, in the past these Djerdap villages were poor, there was not fertile land here, people dealt with livestock, you had lambs and cheese-and you lived on that, and, of course, it was important for sheep "to stay in" milk and to lamb, and when Djurdjevdan came everyone tried to maintain customs, what they knew and in the wayin which the old passed those customs to them, you see, many customs were performed in community with other people, you couldn't do anything alone, you had to participate in joint actions in order to make progress... you see, girls liked reading fortunes to find out whom they would marry, so the night before Djurdjevdan they put men's red socks under their pillows so that they could dream about their 'future husband'; it was believed that the guy who would appear in their dreams, would become their husband. Later on, the girl would give the red socks to the young man, and if he liked her, he would give her a blue scarf as a present. And that meant they 'agreed' to be together, which was not a guarantee that the parents would give consent. Why red and blue? - Because these colours meant progress in life and happiness..."
\end{abstract}

\subsection{Marriage arrangements}

After the Second World War until the sixties of the $20^{\text {th }}$ century, in the rural areas of Serbia and in the eastern borderlands, patriarchal family organization of life was smoothly developing, identifying traditional patterns of relations between men and women, i.e. dominance of men over women and "power" of a father over children, which meant that a father made final decisions concerning his children, including their marriage arrangements. Only with the accelerated process of industrialization and urbanization, opening of the country to foreign countries, the patriarchal family gave way to the so-called democratic family (Mladenovic 1995) that transformed relations between spouses and the relations between parents and children. In a democratic family the authority of a father is deregulated and "child-centricity" becomes an important part of a family (Milić 2007). 
By recalling how marriages were arranged in the old Tekija, the one before the creation of the hydropower plant "Djerdap", Đ. Tašić says:

\begin{abstract}
"Parents who had a male or female child in the house, who had already reached the age of 13,14, began to think about the family they would like to become their 'inlaws'; What I want to say is that they began to think aboutthe home they would like to take a bride from or agree to give their daughterto... For example, a guy starts liking a girl, or the other way around- a girl starts liking a boy, but he is from a poor family, then parents immediately say: 'He is poor, how are you going to live?' or they say, 'You see that he is poor, he will not bring a dowry'... A small number of people married for love, just 5-10\%, a lot of things had to match so that those who loved each other could get married in the end... so, parents first checked if afamilywasrich or poor, whether household members were healthy, and whether some concealed illness had been passed in the family from generation to generation. The healthy got married, the sick did not, they did not get a chance... It was closely watched if there were children or women who couldn't have children in that other family, and only when everything was examined and established, parents of that boy and that girl met to discuss together the wedding date, who would prepare what gifts and how they would 'survive" the wedding. Young people didn't havea say in anything, parents arranged all, it was like that in the past, father had the final say, kids listened and did not complain, they didn't dare!"
\end{abstract}

The year is traditionally divided into two parts, summer and winter. The summer part of the year begins with Djurdjevdan and lasts until Mitrovdan (Saint Demetrius's Day) (November 8), those are days during which the most important deals in the year are made, because it is a period when life flourishes, when everything progresses, so it is also a good period to make marriage "deals".

"All things related toa wedding", says Tašić, "are arranged on Djurdjevdan or Mitrovdan. Marriage proposals are done on saintly days. Ah, when 'the deal' is made, prospective bride and groom can meet, walk, but in the presence of anelder-grandparents or uncles, aunts, and only onpublic places, in the market, near the church... In that way young people are given the opportunity to become a little closer, because they will soon start a life together, and thisis to get familiar with each other's natures."

In the past and still now in eastern Serbia young people got married young, atan earlier age than in other parts of Serbia. Another of their specific characteristics concerning birth is the low birth rate - one child in a family. The determinants of such behaviourhave not been fully established; however, from Đ. Tasic's story a number of conclusions can be indirectly drawn:

"Before and after the Second World War in this part of the country girls got married at an early age; as soon as a girl reached 13,14 or entered 15 , she got married, before reaching adulthood. A girl who couldn't get married until 15 was considered 'faulty' and that something was wrong with her, the old people said, so nobody wanted her, she 'expired' and remainedunmarried ... Boysgot married after reaching adulthood, they did not choose themselves who they would marry, elders decided that - parents had a major role. There were, however, boy and girl loves hidden from parents, when the young knew parents would not give consent they secretly met and so elderslater either gave consent or not... By the way, girls couldn't go anywhere alone before marriage, they would always be escorted by a relative, grandmother, mother, brothers or close relatives; young people did not have much opportunities to choose their own partners, nor it was considered proper ... 
In the past, there existed close family ties among almost all the inhabitants in small places, in the countryside, because no one had moved to those villages for ages, and marriages were arranged exclusively within the same village, so that all residents soon became close or distant relatives ... There were not only first-cousin marriages, but also second-cousin and third-cousin marriages, and those marriages were usually without children , and if a child somehow was born, it was the only one... So it was like this, a young girl got married for the first time when she was 13 and a year passed, then year and a half, but she still wasn't pregnant, so those young people split up and immediately entered into a new marriage, there were cases where a girl got married and split up several times until she turned 18, until she gave birth to a child in one marriage, then that marriage became permanent. Therefore, these early marriages were common here to examine which marriage could lead to conception..."

\title{
3.3. Wedding traditions
}

A great significance was given to the solemnization of marriage in almost all cultures, the act itself represented a sort of initiation for the young people who took on the role of spouses becausethat act confirmed that they became mature personalities in the community which they belonged to, able to cope with life's challenges. Therefore, weddings, representing the solemn form of marriage celebrations, were carefully prepared and the main actors, the bride and groom,"played" in detail intended roles for the day so that their future life would be happy and bringthem healthy posterity. In particular, ritualistic behaviour,which protected young people from the so-called evil eye, was developed.

\begin{abstract}
"Mother-in-law and father-in-law, groom's parents", says hale uncle Djordje, "particularly paid attention to anybody trying to 'cast a spell' over the bride on the wedding day, the bride was already seen as the mother of their son's children, they weredetermined to protect her from the evil eye, because their lineage continued and their home was protected through her. That is the reason why a bride in this area on her wedding dayalways wore an object that she had received as a gift from the father-in-law or mother in law, for example, gold jewellery, a woven fabric that was especially designed for the protection against the evil eye... Then, it was important that mother-inlaw welcomed daughter-in-law infront of a doorstep, served her with honey so that her life in the new house would be sweet, and so that she would get on well with her husband and new family members. Mother-in-law thengave her a sieve with grain, then the bride threw that sieve over the roof, whichindicatedthe progress of the house and also that both fields and bride would be fertile in that house.

When the celebration ended, after three days, the known order between the elderly and young was again restored in the family. In a family she was born into, the girl listened to her parents, especially her father. In the family she married into, a young woman now listened obediently to her husband and his parents, both mother-in-law and father-in-law. The older woman makes all decisions, young just listens and as long as mother in-law was alive she had to be asked for permission for anything. The bride was not given time and a special place in the house where she could devote herself to her husband and show him that she loved him, it had to be done secretly".
\end{abstract}

Expression of sexuality in the old patriarchal family that lasted until the seventies in Tekija and surrounding areas, which Đ. Tašić talks about, was covered by strict rules of life shared with multiple generations in a house that often didn't have separate space for young spouses. On the other hand, determined relations between men and women, which were supported by the church (referring to the Orthodox Church), which rested on the women's obedience and men's superiority, clearly criticized the freedom of expression of 
sexuality, which was accepted only if it secured the birth of an offspring. Therefore, the old customsaccompanying Djurdjevdan and other holidays throughout the year in the eastern borderlands of Serbia, which allowed close socialization of young people (staying in the forest during the night, swimming together on Djurdjevdan morning) should be perhaps regarded as traces/ memories of the pre-Christian period in which the celebration of life was not subject to religious, petty bourgeois or some other arrangement.

\section{CONCLUSION}

Questions about the fate of nations, states, societies, economy, technology, media, cyberspace, underwater world and the multitude of other things that seriously affect the quality of human life or that frivolously prefer to incorporate themselves into man's daily routine, cannot compensate, by their number, width, and prevalence, man's need to deliberate about himself and the relationship with another man. Deliberation becomes even more complicated as the man's world is dividedinto the world of men and the world of women: despite the myriads of years they have spent together, both looking for "their other half," the two worlds are mutually attracted as much as they aremutually repelled. Sexuality, as a natural force that can gather them in the common world, because of the social, cultural and religious engineeringto which it has been exposed during all those innumerable years, happens to be, today, a force that separates them; especially because of freedoms in the sphere of sexual orientation, which are not new, but justtaken out of historical mothballs in a new way. Because of that, our story about male-female relationships and sexuality in the eastern borderlands of Djerdapvillages until the mid of the second half of the $20^{\text {th }}$ century, in the way it has been kept in the memory of a Tekija'soctogenarian, may seem archaic; although it is true that it belongs to and describes past times, although it is true that it looks unreal or perhaps out-dated,and probably unnecessary. However, this story presents a link with those generations and times that gave birth to us as we are now, unprepared to see red and blue through the eyes of Tekija's couple in love, His and Hers.

Acknowledgement: Prepared as a part of the project Sustainability of the Identity of Serbs and National Minorities in the Border Municipalities of Eastern and Southeastern Serbia (179013), conducted at the University of Niš - Faculty of Mechanical Engineering, and supported by the Ministry of Education and Science of the Republic of Serbia.

\section{REFERENCES}

Milic, Andjelka. Sociology of the Family. Belgrade: Čigoja press, 2007.

Mladenovic, Marko. Basic Elements of Sociology of the Family. Belgrade: Zavet, 1995.

Vlahovic, Breda. (1996). "Djurdjevdan in Djerdap Villages". In Ethno-cultural Collection of Works, book II, edited by Sreten Petrovic and Nedeljko Bogdanovic, 169-174. Belgrade: SANU (Serbian Academy of Science and Arts); Svrljig: Ethno-cultural workshop, 1996.

Mill, S. J. The Subjection of Women. Belgrade: State printing office, 1871

Prvulovic, Borislav. "Comparative analysis of Djurdjevdan customs in the regions on the Timok and Nišava." In Ethno-cultural Collection of Works, book II, edited by Sreten Petrovic and Nedeljko Bogdanovic, 250255. Belgrade: SANU (Serbian Academy of Science and Arts); Svrljig: Ethno-cultural workshop, 1996.

Stanojevic, Marinko. Collection of Contributions: Introduction to the Timok region. Belgrade: Printing office, "Jovanović", 1930. 


\section{TEKIJA I OKOLINA: LJUBAV U CRVENOJ I PLAVOJ BOJI}

U Đerdapskoj klisuri, stešnjen između kamenitih planina i Dunava, moćnog i tajnovitog, život se odvija u malim naseljima u kojima svi poznaju svakog, a mladići i devojke, kada prekoračuju granicu koja ih prevodi u muškarce $i$ žene, slede običaje svojih predaka. Ugledaju se na starije, slušaju njihove preporuke ukoliko nisu izbegli usudu patrijarhalne socijalne integracije. Ili postupaju slobodno, na način koji sami biraju, ukoliko je poriv da se izbore za pravo na vlastiti izbor u ,pitanjima srca“ dovoljno jak da nadraste bojazan od prekora i kažnjavanja starijih.

Ovde, na razmeđi svetova koje deli velika reka, susreću se tradicije srpska, rumunska, vlaška, dovoljno slične da se mnogi njihovi elementi, naročito kada je o običajima reč, prepliću, malo preoblikuju ili neizmenjeni prihvataju kao sopstveni, čineći život na različitim obalama sličnim. Naročito kada je reč o tzv. muško-ženskim odnosima i izražavanju seksualnosti.

U ovom radu su izložena saznanja o, za pojedinca $i$ zajednicu kojoj pripada, važnim pitanjima izražavanja naklonosti između devojaka i mladića u Tekiji i okolini i ispoljavanju seksualnosti. Razgovor sa Đorđem Tašićem iz Tekije rasvetlio je neka obeležja muško-ženskih odnosa tipičnih za kladovski kraj i istočno pograničje Srbije.

Ključne reči: $L G B T$, pravoslavlje, Srpska pravoslavna crkva, Srbija. 